\title{
Sosyal Bilimler Araştırmacılarının İstatistik Paket Programlarına Karşı Tutumları
}

\section{Attitudes of Social Scientist Towards Statistical Software Packages}

\author{
Ümit IŞIKDAĞ ${ }^{1}$, Sergen CANSIZ², Kemal ŞAHIN³
}

Öz

İstatistik araçları sosyal bilimler araştırmalarında, araş-tırma kapsamında toplanılan verilerin analiz edilebilmesi için sıklıkla kullanılmaktır. Doğru ve geçerli bir analizin yapılabilmesi için araştırmacıların, istatistik yöntemlerine, bu yöntemlerin uygulanışına ve istatistiksel varsayımlara hâkim olmaları gerekmektedir. Bu çalışmada Sosyal bilimler araştırmacılarının, uygulamalı istatistikte hangi zorluklarla karşılaştıklarının ve istatistik yazılımlarında ne gibi eklentilere intiyaç duyduklarının tespit edilmesi hedeflenmektedir. Bu hedef doğrultusunda belirlenen kriterlere uygun katılımcılar ile betimsel bir çalışma yürütülmüş sonucunda da Teknoloji Algı Ölçeği ile katıımcıların istatistik paket programlarına karşı tutumları değerlendirilmiştir.

Anahtar Kelimeler: Sosyal bilimler araştırma yöntemleri, sosyal bilimler istatistik analiz yöntemleri, sosyal bilimler istatistik tutumu

\section{Abstract}

Statistical tools are frequently used in social sciences research to analyze the data that is collected in the context of the research. In order to make a right and valid analysis, researchers should be aware of statistical assumptions, methods, and their application. This study aimed to determine what difficulties social science researchers come accross in applied statistics and what kind of add-ons would they need in the statistical software packages. In line with this goal, the survey was conducted with the students of the Department of Sociology at Mimar Sinan Fine Arts University as a sample group and their attitudes towards the statistical package programs were measured and the results obtained were evaluated.

Keywords: Social science research methods, social sciences statistical analysis methods, statistical attitude of social sciences 


\section{Extended Abstract}

Purpose: Statistical tools are frequently used in social sciences research to analyze the data that is collected in the context of the research. Most of the departments in social sciences faculties provide courses on statistics and statistical analysis software. In parallel with the advancements in computing the use of statistical analysis packages such as SPSS and SAS have increased. These tools facilitate the task in data entry, management and statistical calculations. Although the software packages provide nice interfaces to the users the user needs to be aware of statistical assumptions, methods, and their application in order to utilize the software and reach valid results. In this situation, researchers would need a guide to follow the in order to perform the required statistical calculations. There are several informative web sites, books (and tables in them) and also several web-based software to help the researchers in selecting the right statistical test. In fact in order for the authors to understand and interpret these tables/ or use these tools they have to be familiar with data types and scales, and the distribution of data (to decide on whether parametric or non-parametric test needs to be applied).

Method: Once the researcher finds the right test and conducts it, the researcher again would need guidance in interpreting the results of the test and reporting these results. This stage of the research is very errorprone. In this context this study aimed to answer two main research questions, first was related to determining the expectancies of researcher from statistical software packages, second was related to determining the problems in developing an application to support social science researchers in their statistical analysis. Considering these research questions, the study was focused on determining what type of difficulties social science researchers come across in statistical analysis processes and what kind of add-ons would they need in the statistical software packages to support their analysis process. In the study a survey was conducted with a sampling from the students of Mimar Sinan Fine Arts University Sociology Department, who have taken at least 30 hours of statistical courses and training on statistical package programs. The students were asked to fill a survey consisting of questions to identify and measure their attitudes towards the statistical software packages, and the difficulty levels of the problems encountered in the statistical calculation phases. The first part of the survey included questions that use Likert scale, later the second part questions used a scoring type. The results were evaluated using One Sample T-test and Chi-square statistical tests.

Findings: The results of the study indicated that the researchers found statistical software packages necessary for their analysis, but they found them not easy and interesting to use. It is also found out that the researchers had difficulties reg arding the use of the software packages at all phases of the data analysis process. The research reached an evidence that the reason behind this is the interface of the statistical software packages that were not being user-friendly. This paper presents the details and findings of the research. 


\section{Giriş}

Gerek sosyal bilimler gerek diğer bilim dallarındaki araştırmacılar tarafından yapılan bilimsel araştırmalarda, istatistik ve araçları araştırmanın doğrultusunda toplanan verilerin yorumlanabilmesi ve araştırmanın doğruluğun kanıtlanabilmesi için sıklıkla kullanılmaktadır (Can, 2018). Son yıllarda, Türkiye'deki üniversitelerin sosyal bilimler fakültelerinin çoğunda istatistik dersinin zorunlu olarak işlenmesi buna bir örnektir. Sosyal bilimler kapsamında verilen istatistik derslerinin amacı, öğrencilere araştırma metotlarını ve istatistik kavramlarını anlatabilmektir. Bu sayede öğrenciler, yaptıkları araştırmalarda verilerin nasıl toplanılacağını ve hangi yöntemler kullanılarak yorumlanacağını öğrenmektedirler. Bu becerinin sağlıklı kazandırılması iki önemli etkiyi değersiz kılmaktadır.

Birinci etki; mesleki enformasyonu uygularken profesyonel becerilerinde, matematiğin ve fen bilimlerinin etkisidir. Sosyal bilimler alanında öğretmen adaylarının ve bu alanda araştırma yapan bilim insanlarının en büyük handikaplarından biri eğitim hayatlarında matematik ve fen alanlarına oldukça uzak kalmalarıdır. Kızılcık (2010) yaptığı araştırmalarda göstermiştir ki araştırmaya katılan sosyal bilim öğretmen adayları, fen bilimlerinin doğasını, önemini, bireye ve topluma kazandırdıklarını yeterince bilmemektedir. Gruplarda teknoloji bilinci oluşmuş olmasına rağmen, fen bilimleriyle bağlantısının kurulamadığı tespit edilmiştir. Ayrıca, matematik konusunda önyargılara sahip oldukları net olarak görülmüştür. Katılımcılar, ilgili oldukları alan ile herhangi bir bağlantısı olmadığını belirtmişlerdir. Abak'ın (2002) yaptığı araştırmalarda ise matematik ve fen kavramlarını üzerine deneyimi olan sözel bölüm öğretmenlerinin yenilikçi öğretim metodu geliştirmekte ve aktif rol üstlenmede daha yatkın olduklarını ortaya koymuştur. Karadeniz bölgesinde 240 okulun katılımıyla yürüttüğü araştırmalarda, Bayraktar (2013) öğrencilerin bilimsel araştırmalara bakış açılarını değerlendirmiştir. Bu çalışmasında, katılımcıların, bilimsel süreçlerde matematiğin etkisini düşük olarak nitelendirilmiştir. Oysa, nispeten, sayısal ifadelerin az yer verildiği sosyal bilimlerde dahil yürütülen araştırmalarda toplanılan verilerin analizinde matematik özel bir alanı olan istatistiğin farklı teknikleri yoğun olarak kullanılmaktadır (Feynman, 1995).

İkinci etki ise, bilimsel süreçlerin sağlıklı ve nitelikli yürütülebilmesi için de doğru tekniklerin hatasız kullanılmasıdır. Yükselen (2006), farklı kapsamlarda ve konularda düzenlenen birkaç bilimsel kongredeki yayında kullanılan istatistik teknikleri incelemiş ve ciddi hatalar tespit etmiş, bazı yayında ise bilimsel geçerlilikte sıkıntılar bulmuştur. Benzer durumları inceleyen Erdoğan (2001) araştırmacıların yöntem ve veri analizi konusunda daha özenli ve titiz çalışmalar yürütmesi gerektiğini vurgulamıştır.

Tüm bu etkilerin ortadan kaldırılarak sağlıklı bir süreç elde etmek ve değerli bir çıktı alabilmek için sosyal bilimcilerin matematiğe yatkınlığını ve tutumunu pozitif olarak geliştirmek gerekmektedir. Maales ef literatüre bakıldığı zaman bu durum tam tersi ortaya çıkmaktadır. Temeli matematik bilimine dayanan istatistik, sosyal bilimler öğrencilerinde matematiğe karşı duyulan kaygıdan etkilenmektedir (Pamuk, 2011). Özelikle sosyoloji alanındaki araştırmacıların matematik alt yapısına sahip olmamalarına rağmen istatistiği aktif olarak kullanmak zorunda kalmaktadır. Böyle bir durumda istatistik paket programlarını kullanırken çeşitli zorluklar yaşamaktadırlar. Sosyoloji öğrencilerinin istatistik öğrenimi konusunda Delucchi (2014) ve Deckard (2017) tarafından yapılan araştırmalar incelenebilir. Bu çalışmada öğrencilere verilen istatistik eğitiminin yanı sıra öğrencilerin uygulamalı istatistikte, paket programlarını kullanırken ne gibi zorluklarla karşılaştıklarının tespit edilmesi hedeflenmiştir.

\section{İstatistik Paket Programları}

Bilgisayar teknolojisinin gelişmesi ve yaygınlaşmasıyla birlikte, bilimsel araştırmalarda ve deneylerde yapılan istatistik hesaplarına destek sağlayan SPSS, SAS gibi paket programlarının kullanımı da artmıştır. Kullanıcı ara yüzlerine sahip olan bu paket programlar, kullanıcıya daha kolay bir hesaplama ortamı sağlamaktadır. Bu programların haricinde sosyal bilimler ve biyomedikal alanları için çeşitli istatistik yazılımları da geliştirilmiştir (Faul ve diğ. 2007). Geliştirilen bu yazılımlarda, kullanıcıların araştırmalarında kurdukları hipotezi test edecek istatistik yöntemlerini kolayca seçebilecekleri bir ara yüz sağlamaktadır. Testler sonucunda elde edilen istatistik değerleri, kullanıcının rahatlıkla anlayabileceği şekilde belirtilmektedir. Araştırmacılar bunun gibi yazılımlardan faydalanarak yaptıkları araştırmanın istatistiksel olarak ne kadar güçlü olduğunu test etmektedir. Fakat geliştirilen bu yazııımları kullanabilmeleri için, veri analizinde kullanılan istatistiksel hesaplara hâkim olmaları gerekmektedir. Buna örnek olarak; popülasyondan alınan örnekler üzerine uygulanan istatistik testlerinde; alınan örnekten popülasyonun özelliklerini tahmin eden bir model oluşturmak için toplanılan verilerin tercih edilen istatistik testinin varsayımlarını sağlaması gerekmektedir (Berk \& Freedman, 2003 ve Schervish, 2001). İstatistiksel analiz yazılımları, araştırmacının yaptığı testleri ve ihtiyaç duyulan varsayım kontrollerini yapacak içeriğe sahip olmasına rağmen, araştırmacıyı elde edilen sonuçlara göre yönlendirecek içeriğe sahip değildirler. 


\section{İstatistiksel Analiz ve Araştırma Tasarımı}

Sosyal bilimler veya herhangi bir bilim dalında uygulanılan bilimsel bir çalışmada araştırma tasarımı önemli bir rol oynamaktadır. Araştırmacının örneklem grubunu belirlemesi ve bu örneklem grubu üzerine uygulayacağı deneyin başarılı olması araştırma tasarımının tutarlı olmasına bağııır. Araştırma tasarımında araştırmacının belirlediği örneklemi hangi kriterlere ve ne tür değişkenler üzerinde değerlendireceğine karar vermektedir. Bu bağlamda doğru değişken seçimlerini yapabilmesi için veri analizinde kullanılan veri türlerine ve değişken türlerine hakim olunması gerekmektedir. Değişken, araştırmanın amacı doğrultusunda önemli rol oynamaktadır. Örneğin araştırmacı kurduğu hipotezi bir tahmin model kapsamında kanıtlayacak ise bağımlı ve bağımsız değişken olan açıklayıcı değişken türlerine hakim olmalıdır (Kish, 1959). Bir başka örnek olarak; araştırmacı araştırma tasarımı kapsamında örnekleminde belirli gruplar arasında farklılı̆ı test etmek isterse, gruplarla etkileşim halinde olacak kontrol gruplarını ve farklılığa neden olabilecek bağımsız değişkenlerini belirlemesi gerekmektedir. Değişken türleri araştırma tasarımı doğrultusunda belirlendikten sonra araştırmacı istatistiği kullanarak veri analizi yapmaya başlamaktadır. Sosyal bilimler kapsamında çeşitli deney, anket ve mülakat araştırma yöntemleriyle elde edilen veriler için uygulanabilecek çeşitli veri analizi yöntemleri bulunmaktadır (Sokolovska \& Čobanović, 2010).

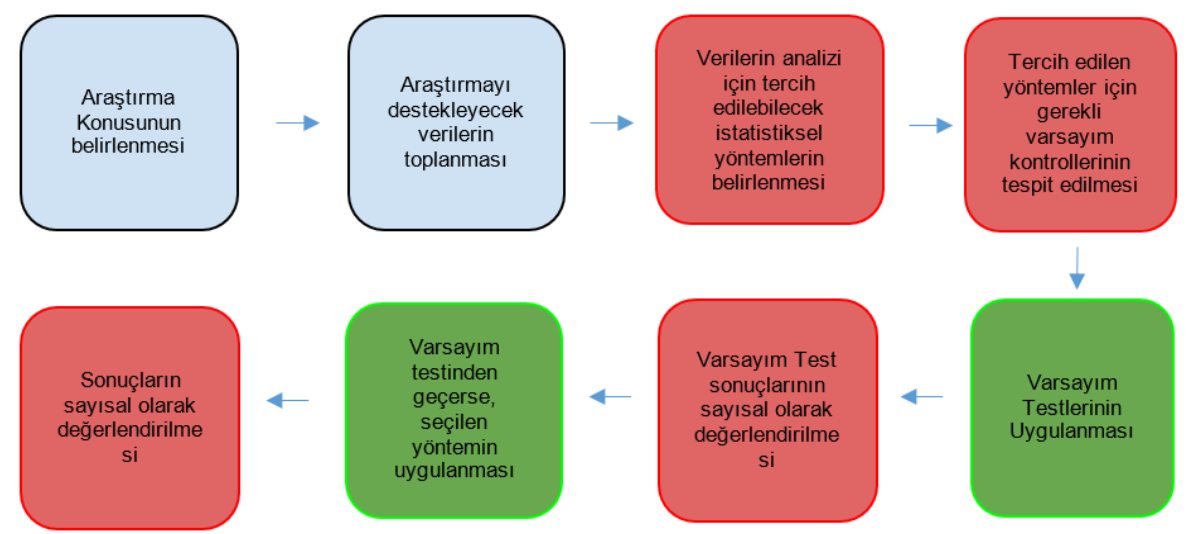

Şekil 1. Sosyal bilimlerde istatistiksel araştırma adımları

Şekil 1'de hedeflenen araştırma için uygulanacak olan analizin aşamaları basitçe gösterilmiştir. Şekil-1 de yer alan şemada mavi olan kutular araştırmacının kendisi tarafından belirlenmesi gereken aşamaları belirtmektedir. Yeşil olan kutular SPSS gibi yaygın olarak kullanılan istatistik hesaplama programlarılla yapılacak olan aşamaları gösterirken, kırmızı olan kutular; araştırmacı tarafından değerlendirilmesi gereken kısımları göstermektedir. Bu çalışmada araştırmacıların kırmııı ile gösterilen kısımları uygularken zorlandıkları düşünülmektedir.

\section{Problem ve Araştırma Soruları}

Sosyal bilimlerde, anketler yardımıyla toplanan verilerin analizi için, grup farklııklarının belirlenmesi, örneklem üzerinden popülasyonda beklenilen değerlerin tespit edilmesi ve temel alınan faktörler arasındaki ilişkinin belirlenmesi üzerine çeşitli istatistiksel testler bulunmaktadır. Belirtilen testler uygulanırken, verilerin türlerine (kategorik, sayısal, sürekli, süreksiz), değişkenlerin istatistiksel dağılımına (gösterdiği parametrik veya parametrik olmayan dağıım şekilleri) göre uygulanabilir test yöntemleri karşılaştırılmalı, aralarından araştırma doğrultusunda kurulan hipotezi anlamlı şekilde test edebilecek yöntem seçilmelidir (Lang 2004). Başlangıç aşaması denilebilecek test seçimi, bir analizin en kritik aşamasıdır. Bu aşamada yanlış yapılan bir tercih elde edilen sonuçlarda tutarsızlığa neden olabilmektedir.

İstatistik test seçimine yardımcı olabilecek birçok Web sayfası ve Tablo 1'de gösterilen tablo gibi rehber tablolar bulunmaktadır. Fakat bu Web sayfaları ve tablolar araştırmacıya yüzeysel bir tercih ortamı sunmaktadır. Araştırmacıların bu tabloları yorumlayabilmeleri için değişkenlerin bağımlılık-bağımsızlık durumları, normallik varsayımları ve bu varsayımlarından yola çıkarak değişkenlerin parametrik veya parametrik olmayan özelikleri gibi çeşitli istatistiksel terimlere hâkim olmaları gerekmektedir (Stein 1981). Tablo-1'de istatistik test seçim tablosu gösterilmiştir. Bu tabloda araştırmacılar topladıkları verilerin türlerine, sürekli veya kategorik değişken sayılarına ve gösterdiği dağılım özelliklerine göre uygulaması gerektiği istatistik testini seçmektedir. Gösterilen istatistiksel testler sosyal bilimciler tarafından sıklıkla kullanılan testlerdendir. Bu tabloyu araştırmacının verimli bir şekilde kullanabilmesi için, önceden değişken durumlarını tespit etmesi ve dağılım şekillerini tespit edecek istatistiksel varsayım testlerini uygulaması gerekmektedir (Hoeffding 1992). Test seçim aşamasından sonra ise araştırmacı, uyguladığı testin sonuçlarının ne gibi anlamlar taşıdığı konusunda rehbere ihtiyaç duyabilmektedir. Elde edilen sayısal değerlerin yorumlanması gibi belirli kurallar çerçe- 
vesinde tamamlanması gereken, "sayısal çıktıların yorumlanması" aşaması oldukça karışık ve hataya müsaittir. Bu tez çalışmasında belirtilen analiz aşamaları göz önünde bulundurulduğunda araştırma soruları şu şekilde belirlenmiştir:

- Sosyal bilimler araştırmacılarının istatistik analizine yardımcı olacak bir uygulamadan (Herhangi paket program) beklentileri nelerdir?

- Sosyal bilimler araştırmacıları için istatistiksel analize yardımcı olacak bir uygulama geliştirilmesinde karşılaşılacak muhtemel sorunlar ve çözüm yolları nelerdir?

\section{Araştırmanın Amacı}

Araştırmanın amacı, sosyal bilimler araştırmacıların, araştırmaları doğrultusunda topladıkları verileri analiz ederken karşılaştıkları problemlerin belirlenmesi ve bu durumu minimize edebilmek için geliştirilebilecek alternatif programların değerlendirilmesidir.

\section{Yöntem}

Araştırmada yöntem olarak betimleme kullanılmıştır. Bu yöntemin tercih edilmesinin ana nedeni, benzer araştırmalarda yaygın olarak kullanılmasıdır. Çepni (2007) bu yöntemi, bir konuyu aydınlatmak, değerlendirme yapmak ve olaylar arasındaki ilişkiyi çıkarmak için en yaygın kullanılan yöntem olarak nitelendirmiştir. Ayrıca, benzer araştırmalarda da bu yöntemin tercih edilmesi bu yöntemin seçimine etki etmiştir (Usta, 2010, Öksüz, 2009, Ekici, 2012).

Sosyal bilimler araştırmacılarının istatistik paket programlarına karşı tutumlarının incelendiği bu çalışmada, araştırma yöntemi olarak anket çalışması seçilmiştir. Anket çalışmasıyla araştırmacıların ilk olarak istatistik ve istatistik paket programlarına karşı tutumları likert ölçeği kullanılarak ölçümlenmiş. Ardından herhangi bir istatistik paket programı kullanırken karşılaştıkları problemleri puanlama yöntemiyle tespit edilebilen bir anket uygulanmıştır.

\section{Örneklem Grubu}

Sosyal bilimlerin bir disiplini olan Sosyoloji bilimi toplum üzerine yaptığı araştırmalarda istatistiği aktif olarak kullanmaktadır. Bu nedenle bu araştırmada örneklem Mimar Sinan Güzel Sanatlar Üniversitesi Sosyoloji Bölümü öğrencilerinden seçilmiştir. Seçilen Örneklem grubunun özellikleri aşağıda belirtirmiştir. Örneklem aşağıdaki kriterlere göre belirlenmiştir.

- Alan derslerinde başarılı ve ders tekrarı olmayan,

- Daha önce istatistik hakkında herhangi bir deneyimi olmayan,

- En az 30 saatlik istatistik paket program eğitimi almış, (Tek bir paket program (SPSS) üzerine odaklanan eğitim içeriği ile)

- Eğitim sonrasında, istatistik paket programı eğitimi kapsamında en az bir veri analizi yapmış,

olma kriterleri esas alınmıştır.

Bu kriterleri yerine getiren Sosyoloji alanında eğitim gören 60 katılımcı belirlenmiştir. Belirlenen örneklem grubunda yer alan her katılımcının 30 saatlik istatistik ve istatistik paket programı dersini düzenli almış ve bu dersin ardından en az bir veri analizi projesini başarı ile tamamlamıştır. Derslere katılım eksik gösteren veya proje tamamlamayan beş katıımcı araştırmaya dahil edilmemiştir. Araştırmadaki katılımcıların eğitimi, veri analizi projelerini tamamlamaları ve değerlendirilmesi yaklaşık olarak üç ay sürmüştür. Akabinde gerçekleşen veri toplama süreci de yaklaşık olarak 15 günde tamamlanmıştır. Eğitim sürecinin uzun olması, bu konuda uzman eğitmen kısıtıılığı nedeniyle katılımcı sayısı 60 olarak belirlenmiştir. Araştırmanın sağlıklı yürütülebilmesi için eğitimler paralel olarak iki oturumda gerçekleştiril-miştir. Her iki oturuma katılan katııımılara aynı eğitim aynı zaman içerisinde verilmiştir.

Veri toplamak için tutum ölçeği kullanılmıştır. Tutum ölçeği olarak, Tınmaz (2004) tarafından geliştirilmiş “Teknoloji Algı Ölçeği" kullanılmıştır. Bu ölçek daha önce, benzer nitelikte ve kapsamda yürütülen araştırmalar kullanılmıştır (Usta, 2010, Öksüz, 2009, Ekici, 2012). Yine Tınmaz (2004) belirttiği şekilde yapılan geçerlilik ve güvenilirlik çalışmasına göre ölçekteki maddeler iki faktörde toplanarak analiz edilmiştir. Birinci faktörün Cronbach Alpha katsayısı 0.89, ikinci faktörün ise 0.81 olarak hesaplanmıştır. Ölçeğin tamamı için ise iç tutarlılık katsayısı 0.86 'dır. Açık uçlu anket çalışmasındaki sorular katıımcıların istatistik paket programlarına yönelik olumlu/olumsuz görüşlerini toplayabilmek için hazırlanmıştır. Böylece elde edilen bulgular daha nitelikli değerlendirebilmiştir. 


\section{Bulgular}

Katılımcıların istatistik ve istatistik paket programlarına karşı tutumlarının veri analizindeki başarılarını etkilediği düşünülmektedir. Bu nedenle ölçek çalışmasının ilk kısmında katıımcıların istatistiğe karşı tutumlarını ölçecek Tablo 1'de belirtilen 6 adet soru yöneltilmiştir ve uygulanılan ölçek doğrultusunda Tablo 2'de yer alan sonuçlar elde edilmiştir.

Tablo 1. Tutum ölçeği kapsamında katılımcılara yöneltilen sorular

\begin{tabular}{clcl}
\hline Soru Numarası & \multicolumn{1}{c}{ Soru } & Soru Numarası & \multicolumn{1}{c}{ Soru } \\
\hline $\mathbf{1}$ & $\begin{array}{l}\text { Mesleğim gereği istatistik } \\
\text { yazılımlarını kullanmayı } \\
\text { öğrenmem gerekir. } \\
\text { Sosyal bilimlerde istatistik } \\
\text { hesaplamalarının ve } \\
\text { istatistiksel yazılımların } \\
\text { gerekli olduğunu } \\
\text { düşünüyorum. } \\
\text { Okulda herhangi bir istatistik } \\
\text { paket programını ders olarak } \\
\text { seçmem benim için faydalı } \\
\text { olur. }\end{array}$ & $\mathbf{5}$ & $\begin{array}{l}\text { Sosyal bilimler alanında uygulanmış } \\
\text { istatistiksel çalışmaları incelemekten } \\
\text { keyif alırım. }\end{array}$ \\
\hline $\mathbf{3}$ & $\mathbf{6}$ & İstatistiksel yazılımların sıkıcı \\
olduğunu düşünüyorum.
\end{tabular}

Tablo 2. Tutum ölçeği sonrası elde edilen sıklık değer

\begin{tabular}{cccccc}
\hline $\begin{array}{c}\text { Soru } \\
\text { Numaraları }\end{array}$ & $\begin{array}{c}\text { Tamamen } \\
\text { Katılıyorum }\end{array}$ & Katılıyorum & Kararsızım & Katılmıyorum & $\begin{array}{c}\text { Hiç } \\
\text { Katılmıgorum }\end{array}$ \\
\hline $\mathbf{1}$ & 9 & 24 & 11 & 6 & 5 \\
$\mathbf{2}$ & 10 & 30 & 8 & 5 & 2 \\
$\mathbf{3}$ & 7 & 29 & 11 & 4 & 4 \\
$\mathbf{4}$ & 4 & 18 & 16 & 13 & 4 \\
$\mathbf{5}$ & 4 & 22 & 19 & 7 & 3 \\
$\mathbf{6}$ & 4 & 14 & 20 & 13 & 4 \\
\hline
\end{tabular}

\section{Katılımcıların İstatistik Paket Programlarına Karşı Tutumları}

Katılımcıların İstatistik ve istatistik paket programlarına karşı tutumlarının istatistiksel olarak hangi yönde olduğunu tespit etmek amacıyla Wilcoxon İ̧̧aret Sıralama Testi uygulanmıştır. 5'li likert ölçeğinde alınan yanıtlar 1 ve 5 arasında skorlanmıştır. Wilcoxon İşaret Sıralama Testi ile \%95 Güven düzeyinde her bir sorudan alınan yanıtların ortanca değerlerinin 3 değerinden küçük veya eşit olma hipotezi test edilmiştir. \%95 Güven düzeyinde yanıtların ortanca değerinin 3 ten büyük olması; yanıtların "Katılıyorum" yönünde, küçük olması; "Katılmıyorum" yönünde olduğunu göstermektedir. Tablo 4'de Wilcoxon Testinden elde edilen istatistikler yer almaktadır.

Tablo 3. Tutum ölçeği; Wilcoxon işaret sıralama testi istatistikleri

\begin{tabular}{|c|c|c|c|c|c|c|}
\hline \multirow{3}{*}{$\begin{array}{c}\text { Soru } \\
\text { Numaraları }\end{array}$} & \multirow{3}{*}{$\begin{array}{l}\text { Örnek } \\
\text { Sayısı }\end{array}$} & \multirow{3}{*}{$\begin{array}{l}\text { Pseudo } \\
\text { Medyan }\end{array}$} & \multirow{3}{*}{ V Değeri } & \multirow{3}{*}{ P Değeri } & Medyan & Değerinin \\
\hline & & & & & \multicolumn{2}{|c|}{ \%95 Güven Aralığı } \\
\hline & & & & & At Değer & Üst Değer \\
\hline 1 & 55 & 3.999 & 709.5 & 0.00453 & 3.000007 & 4.000024 \\
\hline 2 & 55 & 4.000 & 955 & 0.00000 & 3.999932 & 4.000041 \\
\hline 3 & 55 & 3.999 & 766 & 0.00042 & 3.999988 & 4.000023 \\
\hline 4 & 55 & 3.000 & 430 & 0.27810 & 2.999990 & 3.999987 \\
\hline 5 & 55 & 3.999 & 462 & 0.01536 & 3.000015 & 4.000055 \\
\hline 6 & 55 & 3.000 & 322 & 0.45500 & 2.500002 & 3.500002 \\
\hline
\end{tabular}

Tablo 3'de yer alan istatistik değerlerine göre 1, 2, 3 ve 5 numaralı sorulardan elde edilen $p$ değerleri 0.05 'ten küçük olduğundan dolayı istatistiksel olarak bu sorular için ortanca değerlerin 3 'ten büyük oldukları hipotez kabul edilmektedir. 4 ve 6 numaralı soruların yanıtlarından elde edilen $p$ değerleri 0.05 'ten büyük olduğundan dolayı bu 
sorular için ortanca değerin 3'e eşit veya 3'ten küçük olduğu hipotezi kabul edilmektedir. İstatistiksel olarak \%95 güven düzeyinde katıımcılardan alınan yanıtların 1, 2, 3 ve 5 numaraları sorularda Katılıyorum yönünde, 4 ve 6 numaraları sorularda Katılmıyorum yönünde oldukları tespit edilmiştir. Bu sonuçlar değerlendirildiğinde katılımcıların istatistik yazılımlarını sosyal bilimlerde gerekli buldukları, mesleki olarak intiyaç duydukları ve üniversitede ders olarak seçmeleri gerektiğini düşünmektedir. 5 numaralı sorudan alınan yanıtlara göre ise katılımcıların istatistik yazılımlarını sıkıcı buldukları tespit edilmiştir. 4 ve 6 numaralı sorulardan alınan yanıtlar istatistiksel olarak değerlendirildiğinde katılımcıların sosyal bilimler alanındaki istatistiksel çalışmaları incelemekten keyif almadıkları ve istatistik dersinin tüm öğrencelere ders olarak verilmemesini düşündükleri sonuçlarına varılmıştır. Katılımcıların istatistiksel çalışmaları incelemekten keyif almamalarının nedeni istatistik hesaplamalarını karmaşık veya istatistik yazılımlarını sıkıcı bulmalarıyla ilişkili olduğu düşünülmektedir. Katılımcıların istatistik yazılımlarının bütün öğrencilere ders olarak verilmesine katılmamaları sonucu, istatistik dersinin seçmeli ders olarak tercih ettiklerini göstermektedir.

Tutum ölçeğinde yöneltilen soruların birbirleri arasındaki ilişkiyi tespit etmek amacıyla alınan cevaplar arasındaki Spearman's korelasyon değerleri ve $p$ anlamlılık değerleri Tablo 5'de belirtilmiştir. Korelasyon tablosu incelendiğinde bazı cevaplar arasında pozitif yönde bir ilişki bazı cevaplar arasında negatif yönde bir ilişki tespit edilmiştir. Elde edilen korelasyon değerleri ve $p$ anlamlılık değerlerine göre 1, 2 ve 3 numaralı sorular arasında \%95 güvenilirlik seviyesinde pozitif yönde anlamlı bir ilişki vardır. Bu durumda katıımcıların istatistiği mesleki olarak gerekli bulmaları, sosyal bilimlerde istatistik yazılımlarının gerekli olduğunu düşünmeleri istatistik yazııım dersini seçmelerinin faydalı olacağını düşünmelerini pozitif yönde etkilemektedir. Aynı zamanda 2, 3 ve 4 numaralı soruların aralarındaki anlamlı ilişki incelendiğinde, katılımcıların istatistik eğitimini gerekli bulmaları ve istatistik eğitiminin faydalı olacağını düşünmeleri istatistiksel çalışmaları incelemekten keyif almalarını olumlu yönde etkilemektedir. Bununla birlikte 5- 6 ve $4-5$ numaralı sorular arasında negatif yönde anlamlı bir ilişki tespit edilmiştir. Bu durumda katılımcıların istatistiksel hesaplamaları sıkıcı bulmaları istatistiktik çalışmaları incelemekten keyif almalarını negatif yönde etkilemektedir. Aynı zaman katılımcıların istatistiği sıkıcı bulmaları istatistik dersinin tüm öğrencilere verilmesine katılmaları arasında negatif yönde etkilemektedir.

Tablo 4. Tutum ölçeği korelasyon tablosu

\begin{tabular}{|c|c|c|c|c|c|c|}
\hline $\begin{array}{c}\text { r Korelasyon } \\
\text { p değeri }\end{array}$ & Soru 1 & Soru 2 & Soru 3 & Soru 4 & Soru 5 & Soru 6 \\
\hline \multirow[t]{2}{*}{ Soru 1} & 1 & r: 0.556836 & r: 0.699663 & r: 0.141924 & r: -0.04917 & r: 0.387155 \\
\hline & & $\mathrm{p}: 0.000$ & $\mathrm{p}: 0.000$ & p: 0.301 & p: 0.721 & p: 0.003 \\
\hline \multirow[t]{2}{*}{ Soru 2} & $r: 0.556836$ & 1 & r: 0.606609 & r: 0.353996 & -0.1665 & r: 0.382187 \\
\hline & $\mathrm{p}: 0.000$ & & $\mathrm{p}: 0.000$ & p: 0.008 & p: 0.224 & p: 0.003 \\
\hline \multirow[t]{2}{*}{ Soru 3} & r: 0.699663 & r: 0.606609 & 1 & $r: 0.314365$ & -0.33481 & r: 0.598043 \\
\hline & $\mathrm{p}: 0.000$ & $\mathrm{p}: 0.000$ & & p: 0.019 & p: 0.0435 & $\mathrm{p}: 0.000$ \\
\hline \multirow[t]{2}{*}{ Soru 4} & r: 0.141924 & r: 0.353996 & r: 0.314365 & 1 & -0.27326 & r: 0.097289 \\
\hline & p: 0.301 & p: 0.008 & p: 0.019 & & p: 0.043 & p: 0.479 \\
\hline \multirow[t]{2}{*}{ Soru 5} & r: -0.04917 & r: -0.1665 & $r:-0.33481$ & $r:-0.27326$ & $r: 1$ & r: -0.33141 \\
\hline & p: 0.721 & $\mathrm{p}: 0.224$ & p: 0.012 & p: 0.043 & & p: 0.013 \\
\hline \multirow[t]{2}{*}{ Soru 6} & r: 0.387155 & r: 0.382187 & r: 0.598043 & r: 0.097289 & $r:-0.33141$ & $r: 1$ \\
\hline & $\mathrm{p}: 0.003$ & $\mathrm{p}: 0.003$ & $\mathrm{p}: 0.000$ & p: 0.479 & $\mathrm{p}: 0.013$ & \\
\hline
\end{tabular}

\section{İstatistik Paket Programını Kullanım Zorluklarının Tespiti}

İstatistiksel veri analizi uygularken gerçekleştirilecek olan aşamalar göz önüne alınarak düzenlenen ölçeğin bu kısmında katıımcıların veri analizi sürecinde, hangi aşamalarında zorlandıklarının belirlenmesi hedeflenmiştir. Yapılan anket çalışmasında katılımcılara Tablo 6'da belirtilen aşamalarda ne derece zorlandıklarını 1'den 10'a kadar puanlamaları istenmiştir.

Tablo 5. İstatistiksel veri analizi aşamaları

\begin{tabular}{cc}
\hline Aşama & Veri Analizi Aşamaları \\
\hline 1 & Veri Transferi \\
2 & Değişken Türlerini Belirleme \\
3 & İstatistiksel Test Seçimi \\
4 & İstatistiksel Test İçin Değişken Seçimi \\
5 & İstatistikse Değerlerin Yorumlanması \\
\hline
\end{tabular}


Tablo 5'de yer alan veri analizi aşamalarında ne kadar zorlandıklarını ölçen sorulardan elde edilen yanıtların istatistikleri Tablo 6'da gösterilmiştir. Elde edilen yanıtlar Tek Örneklem T-Testi kullanılarak \%95 güven düzeyinde ortalama zorluk derecelerinin güven aralığı (alt ve üst değerleri) elde edilmiştir. Elde edilen ortalamaların güven aralıkları Şekil 2'de yer alan grafikte görselleştirilmiştir. Tüm aşamalar Tek Örneklem T-Testi ile 5'ten büyük hipotezi üzerinden test edilmiştir. Beklenen ortalama zorluk derecesinin 5 değerinden istatistiksel anlamlı olarak büyük olması durumdan öğrencilerin bu aşamada zorlandığı hipotezi kabul edilmektedir. Tablo 6 'da elde edilen istatistik değerleri incelendiğinde tüm aşamalarda $p$ değerlerinin 0.05 'ten küçük olduğu görülmektedir. Bu durumda zorluk derecesinin 5 'ten büyük olması \%95 güven düzeyinde beklenmektedir. Bu sonuç öğrencilerin istatistik paket programı kullanırken zorlandıklarını göstermektedir. Ayrıca öğrencilere istatistik hesaplamalarını uygularken rehber bir uygulamaya ne kadar ihtiyaç duyduklarını ölçen bir soru yöneltirmiştir. Bu sorudan alınan yanıtların istatistikleri Tablo 7'de gösterilmektedir. Elde edilen istatistik değerleri incelendiğinde sosyoloji öğrencilerinin yardımcı bir uygulamaya yüksek oranda ihtiyaç duydukları söylenebilir.

Tablo 6. Veri analizi aşamalarından elde edilen istatistikler

\begin{tabular}{cccccccc}
\hline Aşamalar & Ortalama & $\begin{array}{c}\text { Standart } \\
\text { Sapma }\end{array}$ & Alt Değer & Üst Değer & $\begin{array}{c}\text { Serbestlik } \\
\text { Derecesi }\end{array}$ & T Değeri & P Değeri \\
\hline Aşama 1 & 5.763 & 2.660 & 6.484 & 5.042 & 54 & 2.123 & 0.0191 \\
Aşama 2 & 6.400 & 2.521 & 7.081 & 5.718 & 54 & 4.110 & 0.0000 \\
Aşama 3 & 6.545 & 2.515 & 7.225 & 5.865 & 54 & 4.556 & 0.0000 \\
Aşama 4 & 6.472 & 2.936 & 7.266 & 5.678 & 54 & 3.719 & 0.0002 \\
\hline
\end{tabular}

Tablo 7. Yardımcı uygulama yanıtlarının istatistikleri.

\begin{tabular}{ccccccc}
\hline Ortalama & $\begin{array}{l}\text { Standart } \\
\text { Sapma }\end{array}$ & Alt Değer & Üst Değer & $\begin{array}{l}\text { Serbestlik } \\
\text { Derecesi }\end{array}$ & T Değeri & P Değeri \\
\hline 7.327 & 2.625 & 8.036 & 6.617 & 54 & 6.574 & 0.0000 \\
\hline
\end{tabular}

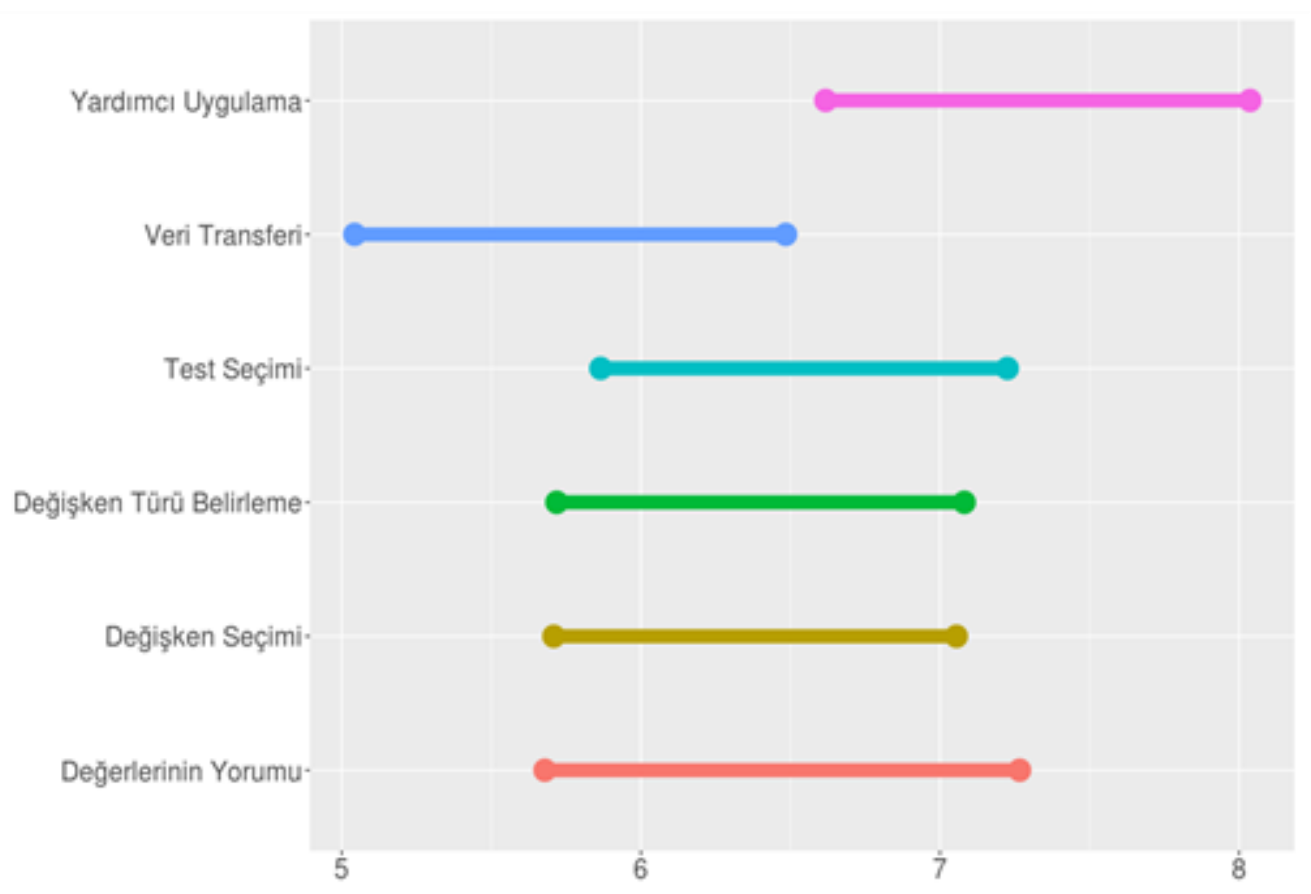

Şekil 2. Katılımcıların istatistik paket programlarını kullanırken zorlandıkları aşamaların zorluk skorlarını gösteren grafik 
Katılımcıların istatistik yazılımlarını kullanırken veri analizi aşamalarındaki zorlanma dereceleri ile istatistik ve istatistik paket programlarına karşı tutumları arasındaki ilişki incelenmiştir. Tüm aşamaların her bir katılımcı için ortalama zorluk derecesi hesaplanarak her bir tutum ile arasındaki korelasyon değerleri elde dilmiştir. Elde edilen korelasyon değerleri ve $p$ anlamlılık değerleri Tablo 8 'de gösterilmektedir. Korelasyon değerlerine göre istatistiğin sosyal bilimlerde gerekli bulunması ve istatistiksel çalışmaların incelenmesinden keyif alınması arasında negatif bir ilişki tespit edilmiştir. Elde edilen $p$ değerleri 0.05 değerine oldukça yakın oldukları için bu ilişkiler $\% 90$ güven düzeyinde anlamlı olarak kabul edilebilirler. Bu durumda katılımcıların istatistiği sosyal bilimlerde gerekli bulmaları ve istatistiksel çalışmaları incelemekten keyif almaları veri analizi aşamalarında zorlanma derecelerini azaltmaktadır. Diğer tutumların korelasyon p değerlerinin 0.05 'ten oldukça büyük olduğu için aralarında anlamlı ilişki olduğunu söyleyemeyiz.

Tablo 8. Ortalama analiz aşamaları zorlukları ve tutumlar arasında elde edilen korelasyon değerleri

\begin{tabular}{lcc}
\hline \multicolumn{1}{c}{ Tutum } & Spearman's r & P- Değeri \\
\hline İstatistiğin mesleki gerekliliği & -0.101 & 0.4608 \\
İstatistiğin sosyal bilimlerde gerekliliği & -0.253 & 0.0657 \\
İstatistik dersinin alınmasının faydası & -0.114 & 0.4000 \\
İstatistiksel çalışmaların ilgi çekicilik & -0.227 & 0.0990 \\
İstatistiksel hesaplamaların sıkıcı ve yoruculuğu & 0.249 & 0.6617 \\
İstatistiğin tüm öğrencilere ders olarak verilmesi & -0.114 & 0.4035 \\
gerekliliği & & \\
\hline
\end{tabular}

Sosyoloji öğrencilerinin paket programlarını kullanırken karşılaştıkları zorlukların birbiri arasındaki ilişki gösteren Spearman's korelasyon ve p anlamlılık değerleri hesaplanmıştır. Elde edilen korelasyon değerleri Tablo 9'da gösterilmektedir. Korelasyon testi sonuçlarına göre katıımcıların istatistik paket programlarını kullanırken belirlenen aşamalardaki zorlanma skorlarının birbiriyle pozitif yönde anlamlı ilişkili olduğu saptanmıştır. Bu bulgura dayanarak katılımcıların herhangi bir aşamada zorlanması diğer aşamalarda zorlanabileceğini göstermektedir. Örneğin; 0.85 oranıyla en yüksek ilişki Aşama 4 ile Aşama 3 arasındadır. Bu durumda, İstatistik test için değişken seçiminde zorlanan öğrencilerin istatistik test seçiminde de zorlanması beklenmektedir. Özet olarak korelasyon sonuçları yorumlanırsa, istatistikte veri analizinin aşamalarının bir bütün olduğu söylenilebilmekle birlikte herhangi bir aşamanın sonuçlanmasında zorluk çeken bir öğrencinin diğer aşamalarda da zorlanması olası bir sonuçtur.

Tablo 9. İstatistiksel Tutum ve aşama zorluk skorları arasındaki korelasyonlar

\begin{tabular}{|c|c|c|c|c|c|}
\hline $\begin{array}{l}r \text { Korelasyon } \\
p \text { değeri }\end{array}$ & Aşama 1 & Aşama 2 & Aşama 3 & Aşama 4 & Aşama 5 \\
\hline \multirow[t]{2}{*}{ Aşama 1} & $r: 1$ & $r: 0.6038$ & $r: 0.4751$ & $r: 0.6245$ & $r: 0.5537$ \\
\hline & & $p: 0.0000$ & $p: 0.0002$ & $p: 0.0000$ & $p: 0.0000$ \\
\hline \multirow[t]{2}{*}{ Aşama 2} & $r: 0.6038$ & $r: 1$ & $r: 0.8001$ & $r: 0.8393$ & $r: 0.6868$ \\
\hline & $p: 0.0000$ & & $p: 0.0000$ & $p: 0.0000$ & $p: 0.0000$ \\
\hline \multirow[t]{2}{*}{ Aşama 3} & r: 0.4751 & r: 0.8001 & $r: 1$ & $r: 0.8559$ & $r: 0.693$ \\
\hline & $p: 0.0002$ & $p: 0.0000$ & & $p: 0.0000$ & $p: 0.0000$ \\
\hline \multirow[t]{2}{*}{ Aşama 4} & $r: 0.6245$ & $r: 0.8393$ & $r: 0.8559$ & $r: 1$ & $r: 0.736$ \\
\hline & $p: 0.0000$ & $p: 0.0000$ & $p: 0.0000$ & & $p: 0.0000$ \\
\hline \multirow[t]{2}{*}{ Aşama 5} & $r: 0.5537$ & $r: 0.6868$ & $r: 0.6939$ & $r: 0.7369$ & $r: 1$ \\
\hline & $p: 0.0000$ & $p: 0.0000$ & $p: 0.0000$ & $p: 0.0000$ & \\
\hline
\end{tabular}

\section{Sonuçlar}

Bu çalışmada Sosyal bilimler araştırmacılarının istatistik paket programlarına karşı tutumları, tutum ölçeği ve kullanım zorluğu teknolojiye karşı tutum ölçeği ile incelenmiştir. Tutum ölçeğinden elde edilen bulgular, öğrencilerin istatistik paket programlarını gerekli gördüğü fakat aynı zamanda sıkıcı ve zor buldukları yönündedir. Kullanım esnasında zorlandıkları ve kavram kargaşası yaşadıkları elde edilen veriler ışığında tespit edilmiştir. Bu durumda sosyal bilimler alanında araştırmacılara yönelik hazırlanan istatistik paket programı eğitimlerinin daha basit ve 
anlaşılır paket programlarla veya sosyal bilimlere özel geliştirecek olan rehber bir uygulama üzerinden yapılmasında fayda olabileceği söylenebilir. Gelecek çalışmalarda, sadece bu alana yönelik özel geliştirilecek bir araç ile çalışma tekrarlanabilir ve bulgular kıyaslanabilir. Böylece, sosyal bilimcilerin tutumlarının araca yönelik mi yoksa istatistiğe yönelik mi olduğu değerlendirilebilir.

Katılımcıların istatistik paket programlarını kullanırken hangi aşamalarda zorlandıklarını ölçüldüğünde, veri analizi için gerekli görülen aşamaların hepsinde zorlandıkları sonucuna varılmıştır. Katılımcıların istatistik paket programları kullanırken veri analizi aşamalarındaki zorlanma skorları ile istatistiğe karşı tutumları arasındaki anlamlı ilişkinin az sayıda olması, veri analizi aşamalarında karşılaşılan zorlukların, bilgisayar okuryazarlığı ya da paket programın kullanıcı dostu olmadığından kaynaklandığını gösterir denilebilir. Bu sonuç bize sosyal bilimler alanına özelleştirilmiş, anket veya herhangi toplum üzerine yapılan araştırmalar için kullanılabilecek özelleştirilmiş bir paket program gerekliliğini, geliştirilen paket programın kullanıcı dostu olması ve sosyal bilimler araştırmacıları tarafında anlaşılabilecek basit bir kullanıcı arayüzüne sahip olması gerektiğini gösterebilir. Öğrencilere yöneltilen; istatistik hesaplamaları için yardımcı bir uygulamaya ne kadar ihtiyaç duydukları sorusunun yanıtların yüksek oranda ihtiyaç duydukları yönünde olması bu sonucu destekler niteliktedir.

Sosyoloji öğrencileri örneklemi üzerinden gerçekleştirilen bu çalışma farklı örneklemler de farklı sonuçlar gösterebilir. Sosyal bilimlerin farkı ılanındaki öğrenciler farklı bir tutum gösterebilir. İstatistik paket programlarının Sosyal bilimcilere özel biçimlendirilmesi veya geliştirilmesi amacıyla ileriki çalışmalarda matematik ve istatistiksel hesaplamaları kolaylaştıran ve kullanıcıları açıklamalarla yönlendiren bir uygulama geliştirilerek öğrencilerin istatistikteki başarıları ölçülebilir.

\section{Kaynakça}

Abak, A. (2002). Üniversite öğrencilerinin fizikle ilgili seçilmiş duyuşsal karakteristikleri ile fizik başarılarının ilişkisi, IV. Fen Bilimleri Eğitimi Kongresi, Ankara: Milli Eğitim Bakanlığı Yayınevi.

Berk, R.A. \& Freedman, D.A. (2003). Punishment, and Social Control. Statistical Assumptions as Empirical Commitments, 235-254.

Bayraktar, ş. (2003). Türkiye'de Ortaöğretim Düzeyinde Fen Bilimleri Öğrenci Başarısındaki Cinsiyete Dayalı Farklılıklar Erişim: Kasım 2003, http://www.yok.gov.tr

Can A. (2018). SPSS ile Bilimsel Araştırma Sürecinde Nicel Veri Analizi, Pegem Akademi, 6.Baskı

Čobanović, K. \& Sokolovska, V. (2010) Use of Statiscal Methods in Sociology, Ministry of Science of Republic of Serbia, Proje No 149013D, No. 149007.

Çepni, S. (2007). Araştırma ve Proje Çalışmalarına Giriş. Trabzon: Celepler Matbaacılık. Geliştirilmiş 3. Baskı.

Faul, F. vd. (2007). G*Power 3: A flexible statistical power analysis program for the social, behavioral, and biomedical sciences. Behavior Research Methods, 39, 175-191.

Delia D. ve Natalie M. (2017) Statistics Education for Undergraduate Sociology Majors: Survey Findings across Institutions. Numeracy 10(2).

Delucchi, M. (2014). Measuring Student Learning in Social Statistics. Teaching Sociology 42(3), 231-239.

Erdoğan, İ. (2001), Sosyal Bilimlerde Pozitivist-Ampirik Akademik Araştırmaların Tasarım ve Yöntem Sorunları, Anatolia: Turizm Araştırmaları Dergisi, 12,119-134.

Ekici, F., Ekici, E., Ekici, F. ve Kara, İ. (2012). Öğretmenlere Yönelik Bilişim Teknolojileri Öz-yeterlik Algısı Ölçeğinin Geçerlik ve Güvenirlik Çalışması. Pamukkale Üniversitesi Eğitim Fakültesi Dergisi, 31 (31), 53-65.

Feynman, R. (1995). What is science? Making physics part of one's life, Paris: United Nations Educational Scientific and Cultural Organisation.

Hoeffding, W. (1948). A Class of Statistics with Asymptotically Normal Distribution. The Annals of Mathematical Statistics, 39, 293-325.

Kızılcık, H. V. (2010) Sözel Bölüm Öğretmen Adaylarının Fen Bilimlerine, Fen Eğitimine ve Teknolojiye Karşı Tutumlarının Araştırılması, Eğitim ve Bilim, 32-146, 80-88.

Kish, L. (1959). Some Statistical Problems in Reseacrh Design. American Sociological Review, 24, 328-338 
Lang, T. (2004). Twenty statistical errors even you can find in biomedical research articles. Croatian Medical Journal, 45(4), 361-370.

Pamuk, M. ve Karakaş, S. (2011). Sosyal Bilimler Öğrencilerinde Matematik Kaygısı: Uzaktan Eğitim ve Kampüs Öğrencileri Üzerine Bir Çalışma, İstanbul Üniversitesi Iktisat Fakültesi Ekonometri ve İstatistik Dergisi, 14, $19-37$.

Öksüz, C. ve Şerife A. (2009). illköğretim matematik öğretiminde teknoloji kullanımına ilişkin algı ölçeği. Yüzüncü Yıl Üniversitesi Eğitim Fakültesi Dergisi, (6)1, 270-287.

Schervish, M.J. (2001). Errors in Statistical Assumptions, Effects of. International Encyclopedia of the Social \& Behavioral Sciences, 4739-4744.

Stein, M. C. (1981). Estimation of the Mean of a Multivariate Normal Distribution. Annals of statistics, 9(6), 11351151.

SPSSUSERS. (2005, Ocak 1). Erişim Ekim 29, 2017, adresinden http://www.spssusers.co.uk/Events/2005/Wireduguide.pdf

Tınmaz, H. (2004). An Assessment of Preservice Teachers' Technology Perception in Relation to Their Subject Area. Unpublished Master Theses. Middle East Technical University. The Graduate School Of Social Sciences

Usta E. ve Korkmaz Ö. (2010) Öğretmen adaylarının bilgisayar yeterlikleri ve teknoloji kullanımına ilişkin algıları ile öğretmenlik mesleğine yönelik tutumları. Uluslararası Insan Bilimleri Dergisi.

Yükselen, C. (2006), 10. Ulusal Pazarlama Kongresi'ne Sunulan Bildirilerde Saptanan Hatalara iliş̧kin Bir Değerleme. Pazarlama ve Pazarlama Araştırmaları Dergisi, 1, 47-51. 